\title{
Orbital mucormycosis in immunocompetent children; review of risk factors, diagnosis, and treatment approach
}

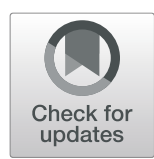

\author{
Ali Amanati ${ }^{1}$, Hamide Barzegar ${ }^{2 *}{ }^{*}$, Gholamreza Pouladfar $^{1}$, Anahita Sanaei Dashti ${ }^{1}$, Mohamad Bagher Abtahi $^{2}$, \\ Bijan Khademi ${ }^{3}$, Mohammad Javad Ashraf ${ }^{4}$, Parisa Badiee ${ }^{1}$, Seyedeh Sedigheh Hamzavi ${ }^{1}$ and Ali Kashkooe ${ }^{2^{*}}$
}

\begin{abstract}
Background: Orbital mucormycosis is a rare but potentially severe and troublesome invasive fungal infection that could be occurred even in healthy individuals. The initial clinical presentation is similar to bacterial pre-septal or septal cellulitis, especially in early stages.

Case presentation: Herein, we describe the successful management of a series of five cases presenting with orbital mucormycosis in previously healthy children.

Conclusions: Orbital mucormycosis is extremely rare in healthy children and maybe life-threatening when diagnosis delayed given a similar clinical presentation with bacterial septal cellulitis. Intravenous antifungal therapy with amphotericin B and timely surgical drainage is live-saving.
\end{abstract}

Keywords: Mucormycosis, Orbital, Immunocompetent, Children

\section{Introduction}

Mucormycosis is the third most common invasive fungal infections following candidiasis and aspergillosis [1]. Mucormycosis is a life-threatening infection that could manifest as a local or systemic infection. Due to high mortality and morbidity, early diagnosis and treatment are crucial. One of the most common forms of mucormycosis is rhino-orbito-cerebral infection [2,3]. Local pain, chemosis, multiple cranial nerve palsies, unilateral peri-orbital facial pain, blepharoptosis, proptosis, acute ocular motility changes, ophthalmoplegia, headache, and acute vision loss are the most common signs and symptoms [1]. Diagnosis usually based on the identification of organisms in tissue by histopathology, culture, $\mathrm{KOH}$ preparation and molecular tests [4]. Surgical debridement, in addition to systemic

\footnotetext{
*Correspondence: hamide.barzegar@gmail.com; ali.kashkooe@yahoo.com ${ }^{\dagger}$ Hamide Barzegar and Ali Kashkoie contributed equally to this work.

${ }^{2}$ Shiraz University of Medical Sciences, Namazi Hospital, 7193711351, Zand Ave, Shiraz, Iran

Full list of author information is available at the end of the article
}

antifungal therapy, is the standard treatment approach which should be started early after diagnosis $[5,6]$. In this case series, we present five previously healthy children, primarily presented with orbital cellulitis. Successful treatment and complete cure occurred despite a late diagnosis in all cases.

\section{Case presentation}

Case 1

The 7-month-old girl visited with edema and erythema in the left inferomedial canthus for 6 weeks before admission. Her mother told that they were villagers and lived in a rural place near Shiraz city. They were on vacation in an area around their home. In the spiral orbital computed tomography (CT) scan with contrast, periorbital abscess formation, and evidence of dacryocystitis found. She scheduled promptly for orbital biopsy and abscess drainage. The results of the biopsy and polymerase chain reaction (PCR) was positive for mucormycosis.

(c) The Author(s). 2020 Open Access This article is licensed under a Creative Commons Attribution 4.0 International License, which permits use, sharing, adaptation, distribution and reproduction in any medium or format, as long as you give appropriate credit to the original author(s) and the source, provide a link to the Creative Commons licence, and indicate if changes were made. The images or other third party material in this article are included in the article's Creative Commons licence, unless indicated otherwise in a credit line to the material. If material is not included in the article's Creative Commons licence and your intended use is not permitted by statutory regulation or exceeds the permitted use, you will need to obtain permission directly from the copyright holder. To view a copy of this licence, visit http://creativecommons.org/licenses/by/4.0/ The Creative Commons Public Domain Dedication waiver (http://creativecommons.org/publicdomain/zero/1.0/) applies to the data made available in this article, unless otherwise stated in a credit line to the data. 
Accordingly, systemic amphotericin-B deoxycholate started. Surgical debridement repeated a few days later, given the inadequate clinical response. She discharged after 2-month hospitalization.

\section{Case 2}

A 9-month-year-old girl visited with swelling of the right inferomedial canthus for 6-week before hospital admission. The patient had a history of repeated episodes of epiphora, and she was suspicious of nasolacrimal duct obstruction (NLDO). She had a history of probing and 17day hospitalization in another university-affiliated hospital. One week before admission, her condition got worsen, and she developed peri-orbital edema, and erythema extended to the superior side of the right medial canthus. Marcus Gunn (a relative afferent pupillary defect (Marcus Gunn pupil) which indicates an asymmetric, prechiasmatic, afferent conduction defect [7]) was $1(+)$, and severe peri-orbital edema with severe proptosis detected without any extra-ocular muscle (EOM) disturbance. Mucormycosis cultured on culture and confirmed by histopathologic examination.

\section{Case 3}

18-month boy with right eye proptosis, purulent discharge, and peri-orbital swelling and redness visited in Nemazee hospital. His mother told that his first symptoms begin since 1-month before admission. Mucormycosis confirmed by histopathologic examination and culture. He went under debulking five times during his hospitalization in addition to systemic antifungal therapy.

\section{Case 4}

A 10-month boy was visited by a general physician due to high-grade fever and managed primarily as the common cold. His mother noticed the right peri-orbital erythema after 2 days. Ipsilateral peri-orbital swelling developed gradually. Peri-orbital abscess formation diagnosed on CT-scan, and he underwent emergency debridement. Histopathologic examination revealed nonseptate broad hyphae and tissue PCR become positive for mucormycosis.

\section{Case 5}

An ophthalmologist referred to a 3-year-old previously healthy boy with peri-orbital swelling to Nemazee hospital. He developed acute onset left sub-orbital swelling without significant pain and fever since 6 weeks ago. The child had a history of frequent exposure to corn and fodder storage and hay. Spiral orbital CT-scan performed, which revealed an orbital abscess in the medial aspect of left orbit without any bony destruction or concomitant sinusitis. The patient scheduled for anterior orbitotomy and incisional biopsy. Despite effective antifungal treatment, the patient needed subsequent surgical debridement.

Demographics, duration of symptoms before admission, clinical features, comorbidities, diagnostic approach, predisposing factors, treatment strategy, followup and outcome of studied pediatric patients and also the available previous reports on orbital mucormycosis in healthy individuals are summarized in Table 1.

\section{Laboratory, pathology, immunologic and imaging workup} The white blood cell (WBC) count, hemoglobin ( $\mathrm{Hb})$, and platelet count ranged between $9.7-33.1\left(\mathrm{cell} / \mathrm{mm}^{3}\right)$, 9.9-12.7 (mg/dl), and 383-640 (thousand $/ \mathrm{mm}^{3}$ ), respectively (Table 2). Interestingly, the erythrocyte sedimentation rate (ESR) and C-reactive protein (CRP) values significantly increased in studied cases. All cases underwent specific diagnostic investigation, including molecular tests as we described previously [12], and immunologic workup (Table 2). All patients regularly assessed by orbital/PNS CT-scan and MRI (with and without contrast) initially and serially after surgical intervention until full imaging recovery. Results of serial orbital MRIs have summarized in Figs. 1, 2, 3, 4 and 5. The histopathological examination of the orbital biopsies revealed fungal elements by Hematoxylin and Eosin (H\&E) staining in all studied patients (Fig. 6).

\section{Discussion and conclusion}

Herein, we report orbital mucormycosis in five immunocompetent children without underling disease or known immunodeficiency successfully managed with medical and surgical interventions. Although invasive forms of mucormycosis have been described and well-known in immunocompromised hosts, such as bone marrow transplantation (BMT), aggressive immunosuppressive therapy in hematological malignancies and diabetic patients $[3,13-15]$, it is scarce in healthy individuals $[2,3$, $8-11,16]$. Based on a retrospective global analysis of 101 cases of mucormycosis in France reported by Lanternier et al., all except one have underlying risk factors [17]. Interestingly, the median number of underlying risk factors per patient was 2 , while $29 \%$ of them harbouring $\geq$ three risk factors, including hematological malignancy, HSCT, graft versus host disease (GVHD), diabetes mellitus, corticosteroids, neutropenia, and solid organ transplantation. Eight of 101 cases reported in children with a median age of 13.4 years. The identified underlying conditions were trauma (50\%) and hematological malignancy (50\%), which mainly localized on skin. Sinoorbital and isolated ocular mucormycosis reported in five and one cases, respectively [17].

In another large case series reported by Maureen et al. in 929 cases of mucormycosis, 19\% were immunocompetent without known underlying conditions at the time 


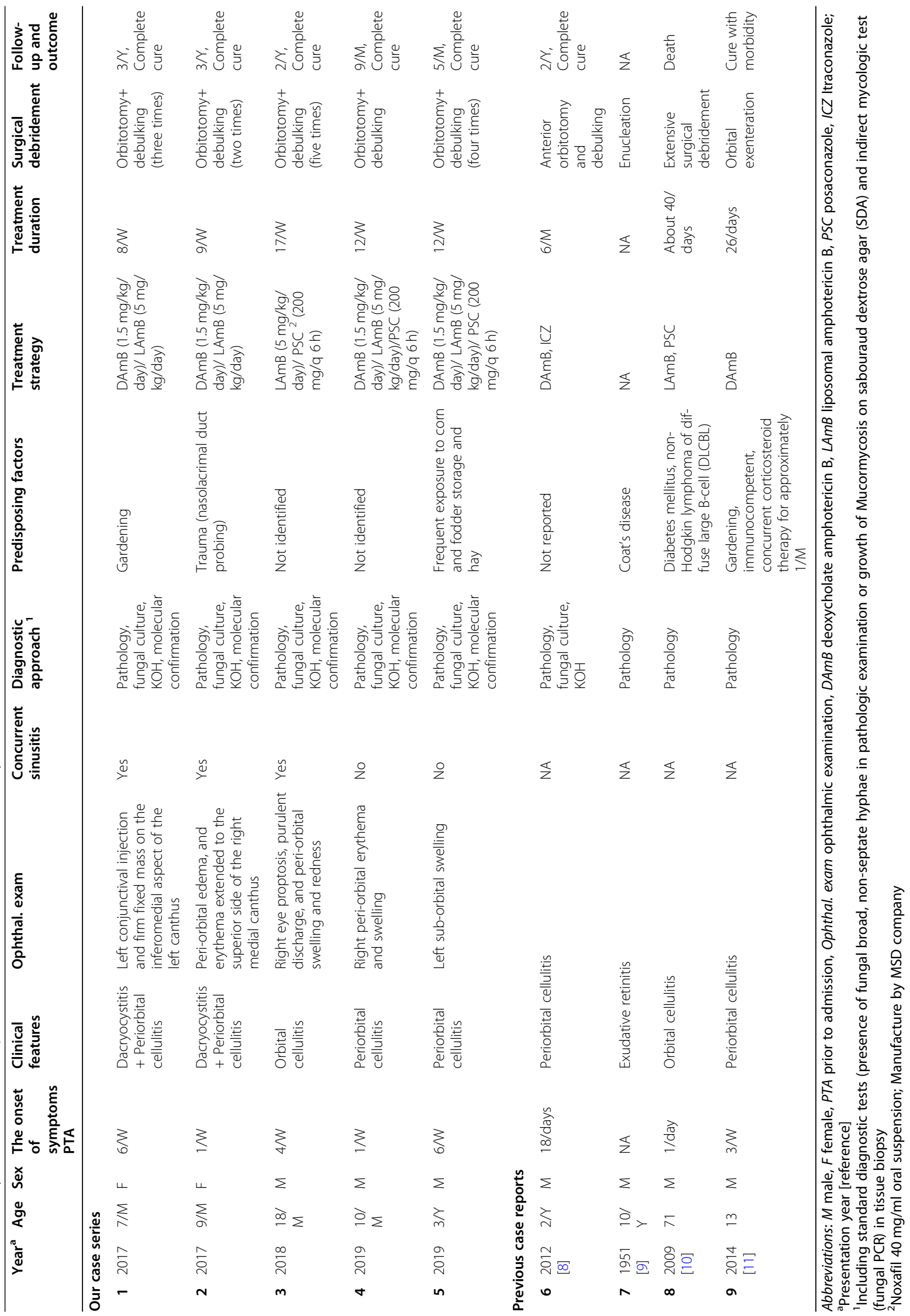


Table 2 Laboratory findings of five cases with orbital mucormycosis

\begin{tabular}{|c|c|c|c|c|c|}
\hline & Case 1 & Case 2 & Case 3 & Case 4 & Case 5 \\
\hline$\overline{W B C}\left(X 10^{3}\right)$ & 9.7 & 12.2 & 33.1 & 10.8 & 17.3 \\
\hline $\mathrm{Hb}(\mathrm{mg} / \mathrm{dl})$ & 12.7 & 10.2 & 11.3 & 9.9 & 10.9 \\
\hline Plt $\left(X 10^{3}\right)$ & 392 & 476 & 640 & 500 & 383 \\
\hline BUN/Cr (mg/dl) & $6 / 0.4$ & $5 / 0.4$ & $12 / 0.5$ & $6 / 0.4$ & $15 / 0.5$ \\
\hline $\mathrm{Na}(\mathrm{mg} / \mathrm{dl})$ & 136 & 141 & 141 & 138 & 142 \\
\hline $\mathrm{K}(\mathrm{mg} / \mathrm{dl})$ & 4.5 & 5 & 4.6 & 4.6 & 5.3 \\
\hline ESR & 41 & 21 & 31 & 22 & 64 \\
\hline CRP & 18 & 7 & $>150$ & 4 & 1 \\
\hline Serum immunoglobulin levels ${ }^{1}$ & $\mathrm{Nl}^{\mathrm{a}}$ & $\mathrm{Nl}^{\mathrm{a}}$ & $\mathrm{Nl}^{\mathrm{a}}$ & $\mathrm{Nl}^{\mathrm{a}}$ & $\mathrm{Nl}^{\mathrm{a}}$ \\
\hline Dihydrorhodamine (DHR) test & 93 & 130 & 167 & 117 & 90 \\
\hline \multicolumn{6}{|l|}{ Peripheral blood flow cytometry ${ }^{2}$} \\
\hline CD3 & $68 \%$ & $56 \%$ & $86 \%$ & $72 \%$ & $59 \%$ \\
\hline CD4 & $37 \%$ & $33 \%$ & $55 \%$ & $39 \%$ & $37 \%$ \\
\hline CD8 & $30 \%$ & $21 \%$ & $28 \%$ & $25 \%$ & $14 \%$ \\
\hline CD16 & $10 \%$ & $5 \%$ & $5 \%$ & $4 \%$ & $13 \%$ \\
\hline CD19 & $22 \%$ & $42 \%$ & $15 \%$ & $23 \%$ & $28 \%$ \\
\hline CD20 & $22 \%$ & $39 \%$ & $15 \%$ & $23 \%$ & $28 \%$ \\
\hline CD56 & $10 \%$ & $5 \%$ & $5 \%$ & $4 \%$ & $13 \%$ \\
\hline Interferon Gamma receptor & Normal & Normal & Normal & Normal & Normal \\
\hline $\mathrm{KOH}$ & $\begin{array}{l}\text { Non-septate broad } \\
\text { hyphae }\end{array}$ & $\begin{array}{l}\text { Non-septate broad } \\
\text { hyphae }\end{array}$ & $\begin{array}{l}\text { Non-septate broad } \\
\text { hyphae }\end{array}$ & $\begin{array}{l}\text { Non-septate broad } \\
\text { hyphae }\end{array}$ & $\begin{array}{l}\text { Non-septate broad } \\
\text { hyphae }\end{array}$ \\
\hline Culture $^{3}$ & Negative & Positive & Positive & Negative & Negative \\
\hline Mucormycosis $P C R^{4}$ & Positive & Negative & Negative & Positive & Positive \\
\hline $\begin{array}{l}\text { Microscopic examination by (H\&E) } \\
\text { staining }\end{array}$ & Positive & Positive & Positive & Positive & Positive \\
\hline
\end{tabular}

WBC White blood cell count, $\mathrm{Hb}$ Hemoglobin, Plt platelet count, $B U N / C r$ blood urea nitrogen/creatinine, Na serum sodium, $K$ serum potassium, ESR Erythrocyte sedimentation rate, CRP C-reactive protein, $H \& E$ Hematoxylin and Eosin (H\&E) staining

${ }^{1}$ Including serum $\lg G, \lg M, \lg \mathrm{A}$, and $\lg E$ levels

${ }^{2}$ Immunophenotyping of the patient's peripheral blood mononuclear cells (PBMCs) Including CD3, CD4, CD8, CD16, CD19, CD20, and CD56

${ }^{3} \mathrm{All}$ isolates were cultured on Sabouraud dextrose agar

${ }^{4}$ Nested PCR was performed with set of primer for Mucormycosis (as authors described previously reference [12])

${ }^{a}$ Within normal limits for age

of infection, penetrating trauma, surgery, and burns were the leading causes. The most localization sites were sinus (39\%; including $8 \%$ Sino-orbital), pulmonary (24\%), cutaneous (19\%), cerebral (9\%), gastrointestinal (7\%), and kidney (2\%). None of the reported cases was isolated ocular mucormycosis [18].

While pulmonary and isolated sinusal, rhinocerebral, rhino-sinuso-orbital, or rhino-orbito-cerebral invasive forms are the most common clinical presentation in immunocompromised patients [1]; invasive mucormycosis usually present as skin and soft tissue infections (SSTIs) in immunocompetent individuals following burn and trauma [19]. However, the site and severity of disease are widely varied based on predisposing factors [2, 3]. Rhizopus oryzae has reported as the most common etiologic cause of rhino-sinuso-orbital mucormycosis [20].

Commonly identified risk factors for orbital mucormycosis consist of hematological malignances (17 to $77 \%$ of cases) $[15,20]$, burn [21], placement of the prosthetic device, [22], post-traumatic (after dental extraction) [23, 24] and diabetes mellitus [2, 3, 25].

Isolated orbital mucormycosis rarely reported in immunocompetent individuals without well-known predisposing factors [16, 26-29] and usually including rhinoorbital, orbito-cerebral, facio-orbital, or other non-isolated forms [30-32].

Early diagnosis is essential to reduce severe morbidity (for example, eye exenteration) and also mortality [6, 11]. Cerebral involvement (CNS seeding) $[18,33]$ and 


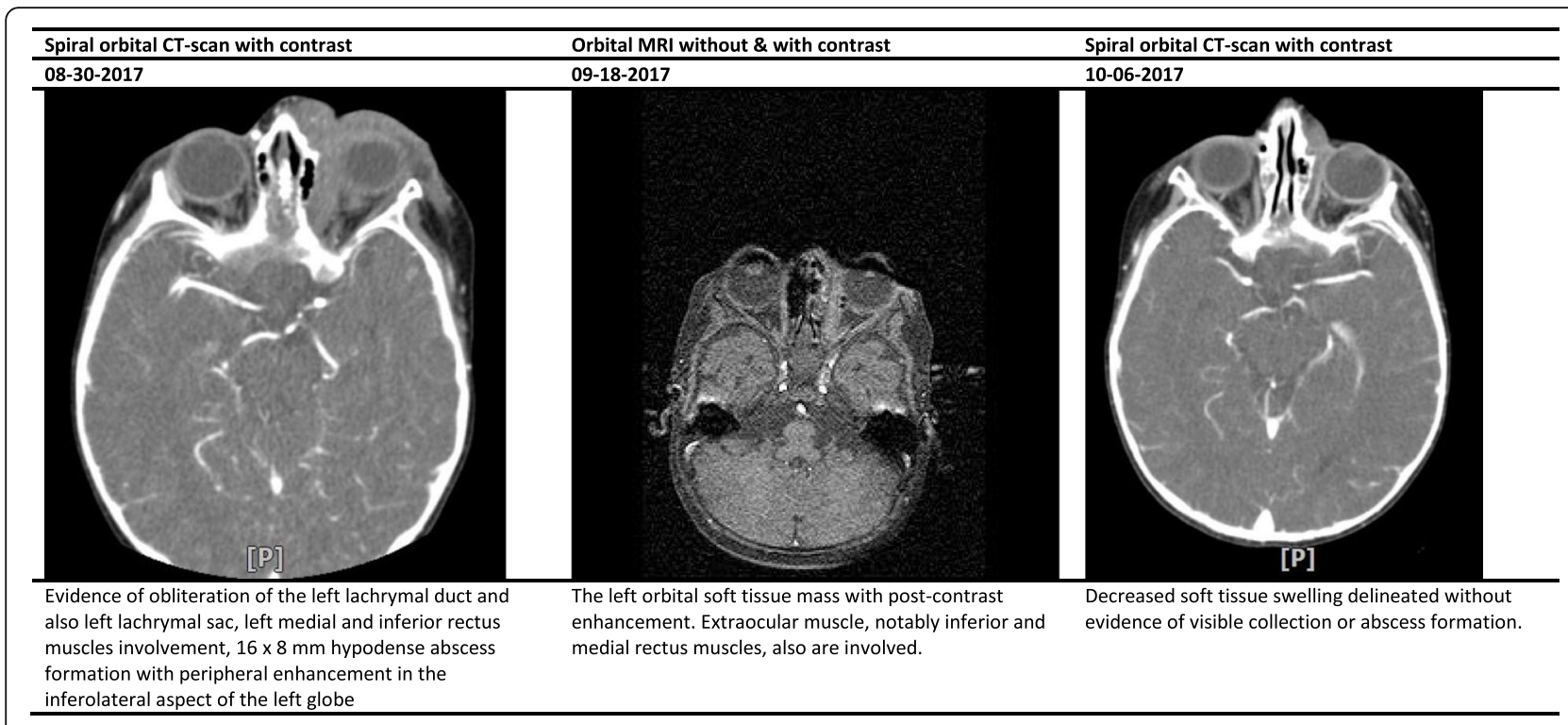

Fig. 1 Summary findings of orbital CT-scan and MRI images at admission and during treatment in case 1

other rare complications, such as orbital apex syndrome [34, 35], also reported in immunocompetent patients.

The standard approach for the treatment of mucormycosis usually based on the combination of liposomal amphotericin B, timely surgical debridement of involved tissues (especially in sinu-orbital and cutaneous forms), and finally control of underlying conditions [19, 36, 37]. Liposomal formulation of amphotericin is preferred, when available, to reduce the risk of infusion-related reaction and nephrotoxicity [38]. Repeated surgical debridement of necrotic tissue is warranted when remaining involved tissue start to progressed despite adequate initial aggressive debridement.

Although the mortality is very high in immunocompromised patients, the prognosis seemed promising

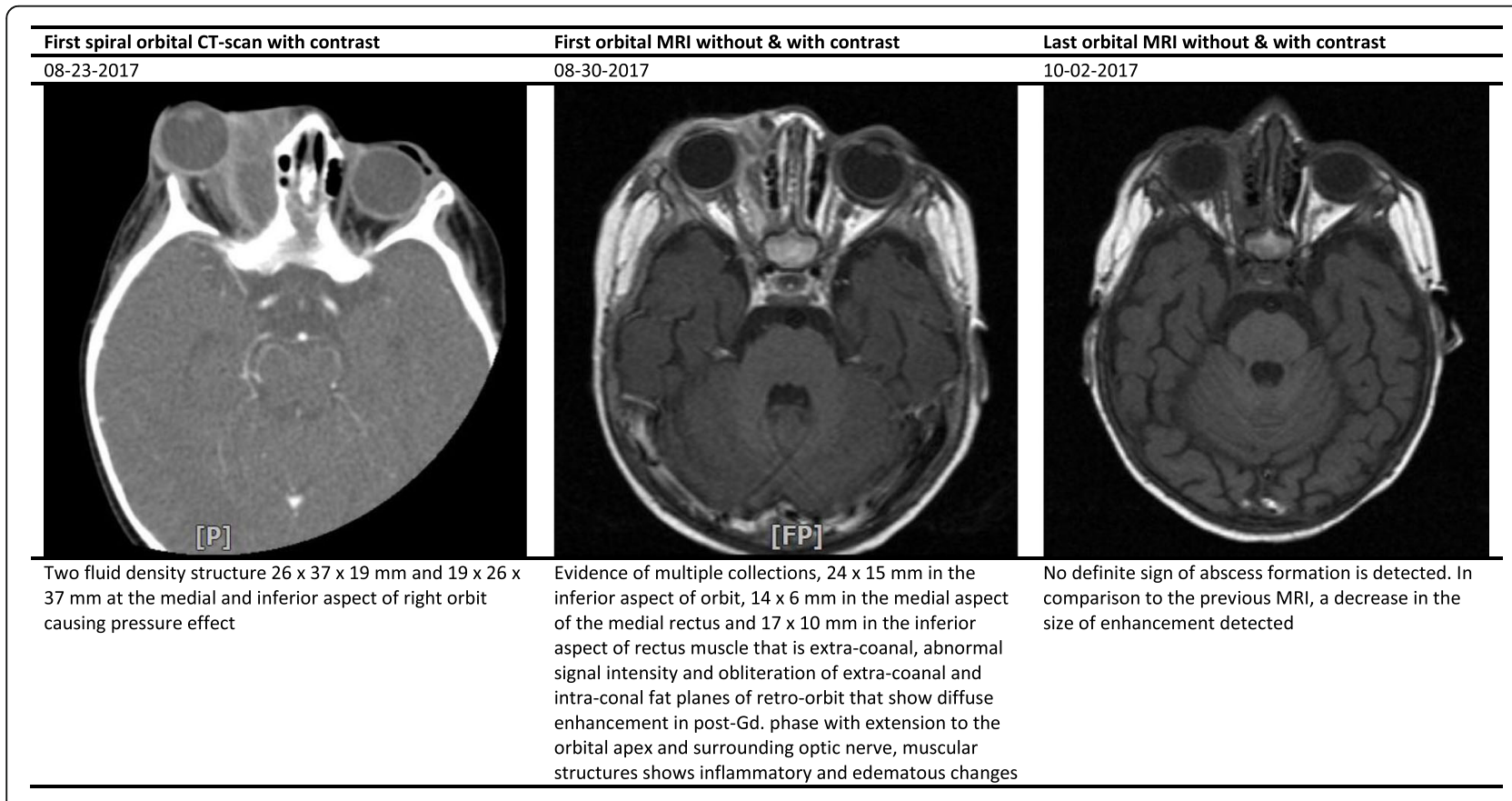

Fig. 2 Summary findings of orbital CT-scan and MRI images at admission and during treatment in case 2 


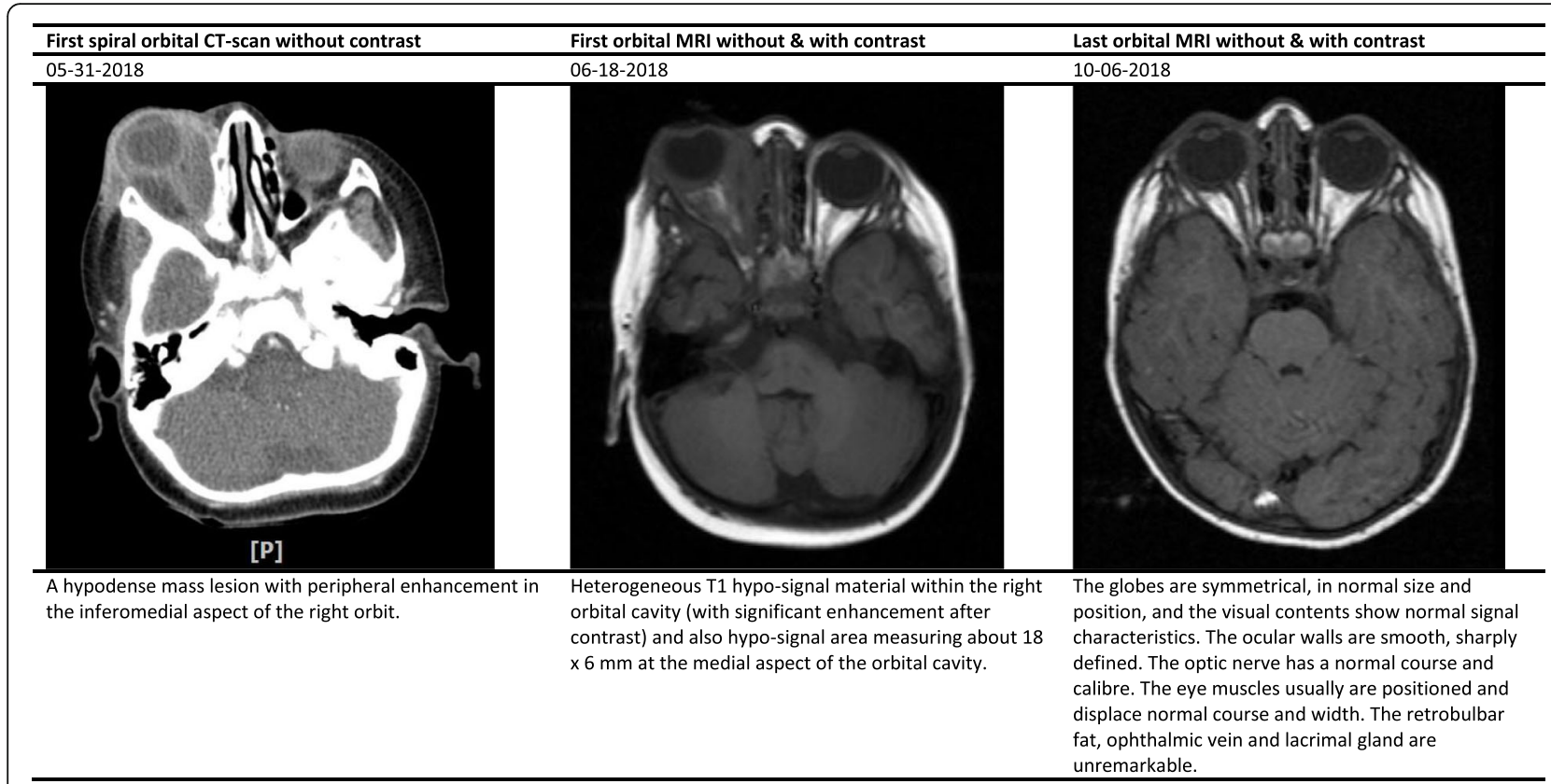

Fig. 3 Summary findings of orbital CT-scan and MRI images at admission and during treatment in case 3

when effective systemic antifungals, early surgical drainage of pus, and orbital decompression considered in immunocompetent children [6, 37]. Delayed effective antifungal therapy (more than 6 days after diagnosis) could result in a 2 -fold increase in mortality rate, as studied by Chamilos et al., in 70 patients with hematologic malignancy [6]. In contrast to other reports, none of the patients undergone aggressive surgical debridement, including exenteration surgery.
The duration of treatment may be related to several factors. An underlying condition, time from illness onset to hospital admission, route of infection, distant seeding (cerebral involvement), age, an early response to treatment, timely surgical intervention, and need for repeated debridement, all could affect the duration of treatment and outcome [18].

As highlighted in Table 1 orbital mucormycosis which presenting with septal cellulitis is quite rare in healthy

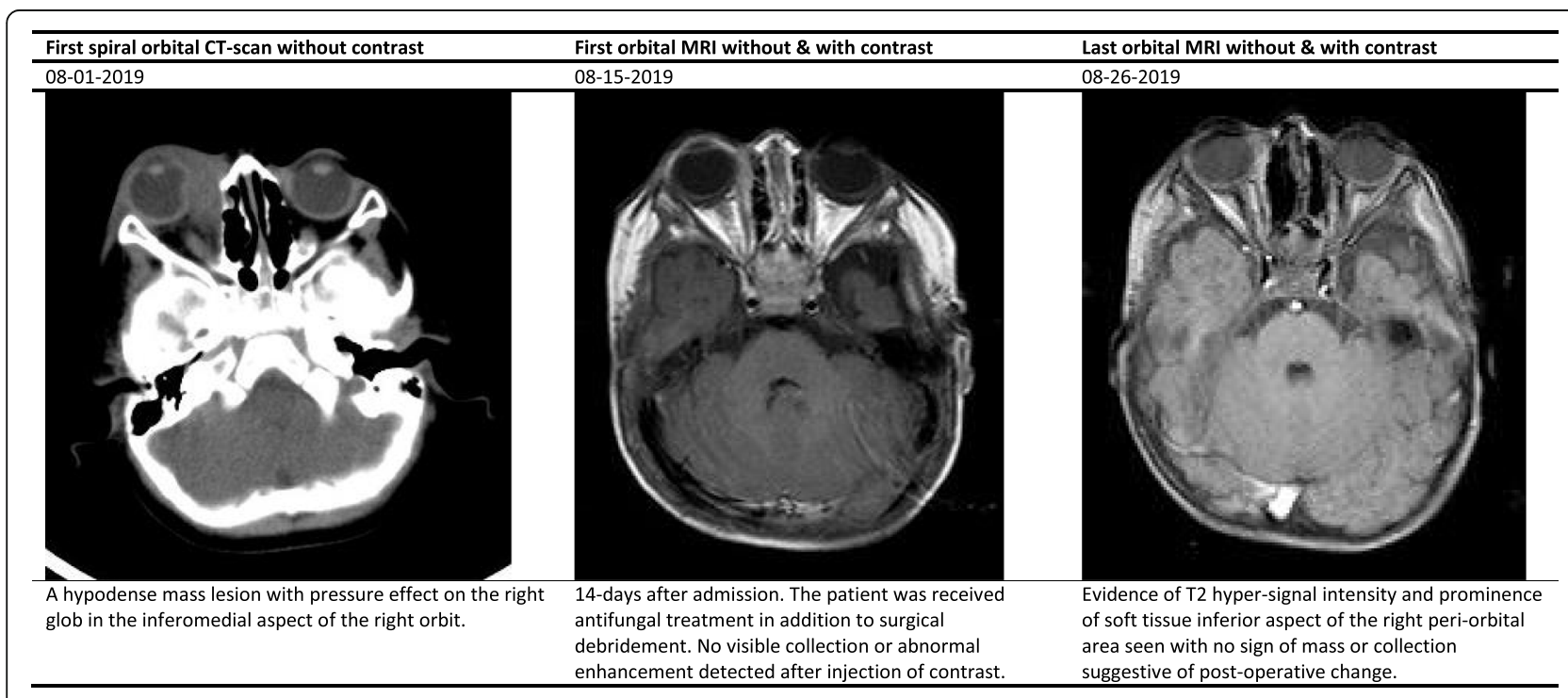

Fig. 4 Summary findings of orbital CT-scan and MRI images at admission and during treatment in case 4 


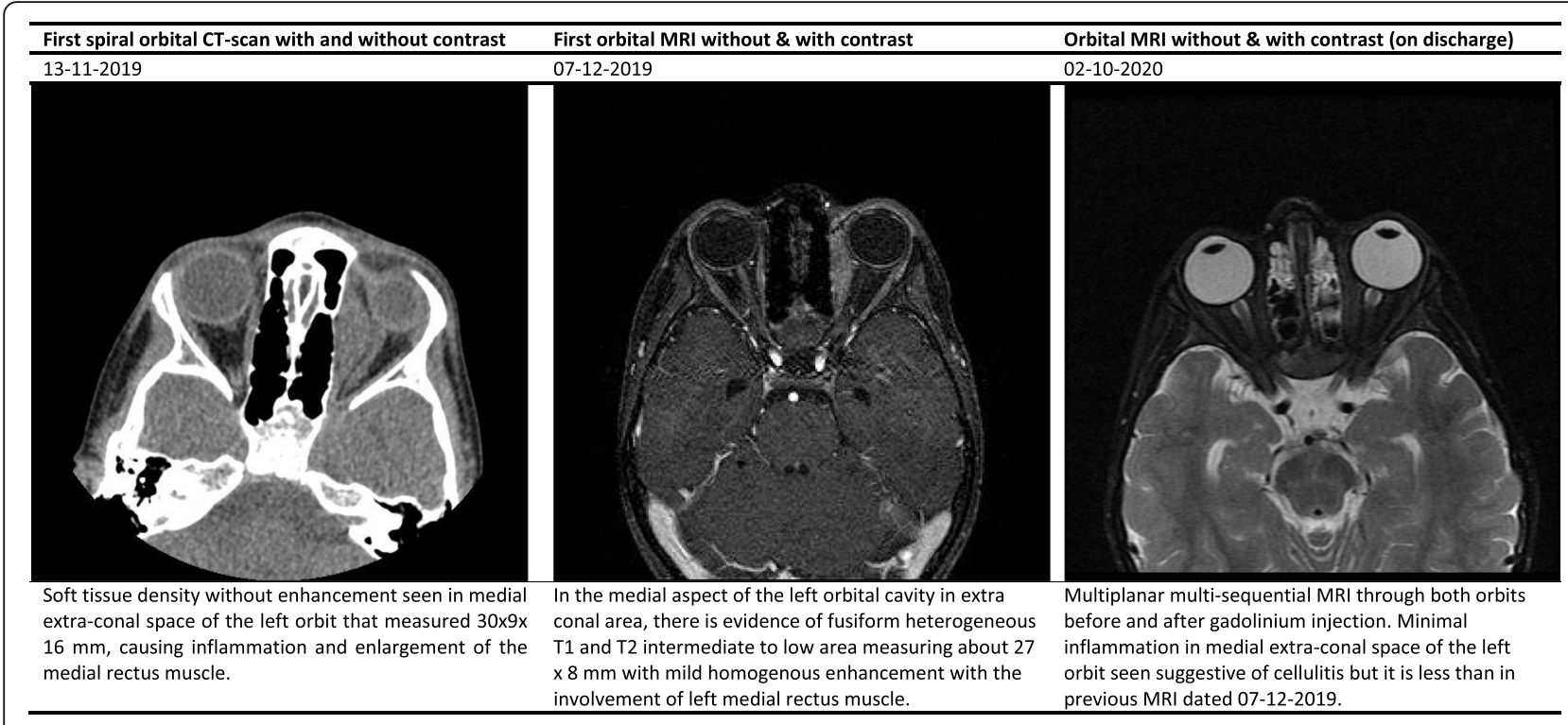

Fig. 5 Summary findings of orbital CT-scan and MRI images at admission and during treatment in case 5

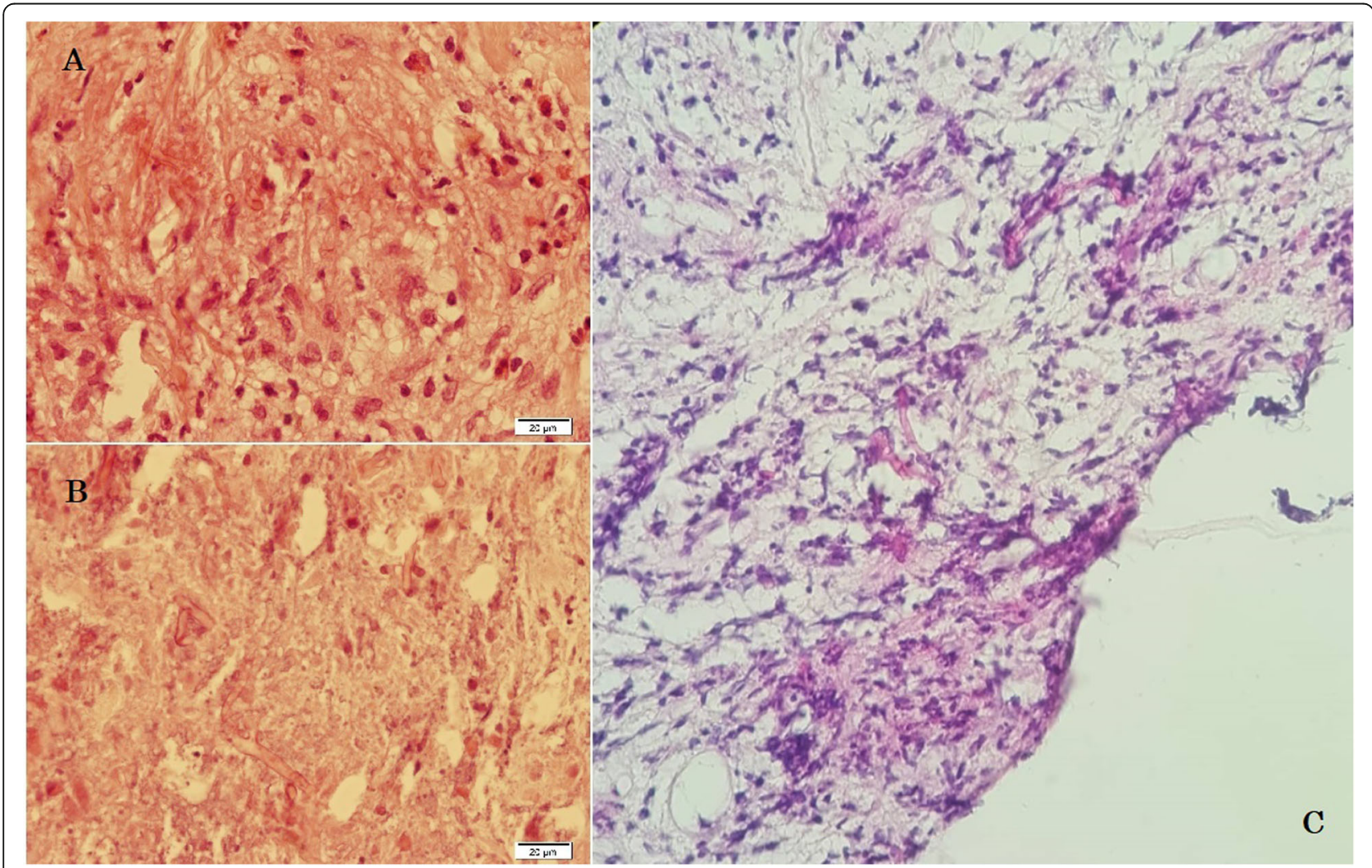

Fig. 6 Non-septate broad hyphae in the necrotic background with acute inflammatory cell infiltration, H\&E stain $(\times 400)$. $\mathbf{a}, \mathbf{b}$, and $\mathbf{c}$ represent a microscopic examination of orbital masses in cases 1, 3, and 4, respectively 
children, so any information regarding the patient's background, predisposing factors, and clinical features of orbital mucormycosis are helpful to guide the physician to suspect invasive mucormycosis in any child with preseptal/septal cellulitis.

The age of infected children is an important finding in our study. The mean age ( \pm Std. Deviation) of studied cases was $16( \pm 11.94)$ months, with a median of 10 months (range between 7 to 36 months).

History of gardening and contact with dust found in two cases. History of iatrogenic trauma (probing) detected in one case. The delay time interval from illness onset to hospital admission is another important finding in our patients. The mean delay time $( \pm \mathrm{SD})$ was $3.6( \pm$ 2.5 ) weeks, with a median of 4 weeks (range between 1 to 6 weeks).

In comparison with bacterial preseptal/septal cellulitis, on admission, laboratory tests revealed comparable ESR but higher CRP levels [39, 40]. The mean ESR/CRP $( \pm S D)$ was $35.8 / 36( \pm 17.7 / 64)$, with a median $31 / 7$. The mean $\mathrm{WBC}$ count $( \pm \mathrm{SD})$ was 16,600 $( \pm 9600)$, with a median of 12,200 (range between 9700 to 33,100), which also was slightly higher than bacterial preseptal/septal cellulitis [39, 40].

Diagnostic orbital CT-scan is another useful and informative modality in the timely diagnosis of orbital mucormycosis. Some experts recommend orbital CT for any children with possible preseptal cellulitis to find other differential diagnoses such as subperiosteal abscess that presented similar to preseptal cellulitis without classic signs and symptoms, including proptosis, visual decrease, or ophthalmoplegia [41]. Based on our experience orbital CT-scan should be advocated in any case of preseptal cellulitis who has marked lid inflammation with edema extending beyond the lid margins, high white blood count elevated CRP levels, and previous antibiotic therapy.

Despite discussion mentioned above, orbital mucormycosis could be developed in the absence of any apparent risk factors (as noted in case 3 and 4), and attention should be paid to the history of gardening, and minor trauma to the lachrymal duct (probing), and exposure to corn and fodder storage and hay in young children.

Finally, to obtain a successful outcome, frequent debridement has a critical role in the management of such patients. To guide timely surgical intervention, serial orbital/PNS CT/MRI, with and without contrast, is mandatory.

In conclusion, these unique cases emphasize the need for a high index of suspicion for the unusual cause of orbital infections, especially fungal infections, in otherwise healthy patients with no apparent predisposing factors. Although mucormycosis predominantly reported in patients with hematological malignancies, it should be considered as part of the initial workup in each patient diagnosed with preseptal/septal cellulitis unresponsive to empirical broad-spectrum antibiotic therapy, high CRP levels, and severe proptosis.

\begin{abstract}
Abbreviations
MG: Marcus Gunn; VA: Visual acuity; EOM: Extra-ocular muscle; CT: Computed tomography; PCR: Polymerase chain reaction; FESS: Functional endoscopic sinus surgery; NLDO: Nasolacrimal duct obstruction; PNS: Paranasal sinus;

MRI: Magnetic resonance image; ER: Emergency room; WBC: White blood cell; Hb: Hemoglobin; ESR: Erythrocyte sedimentation rate; CRP: C-reactive protein; DHR: Dihydrorhodamine test; BMT: Bone marrow transplantation; GVHD: Graftversus-host disease; SSTI: Skin and soft tissue infections; CNS: Central nervous system
\end{abstract}

\section{Acknowledgments}

Our thanks go to professor Alborzi clinical microbiology research center staff for their technical support and assistance.

\section{Authors' contributions}

The study concept and design: AA; Acquisition of data: AA, PB, GRP, ASD, SSH; Consultant ophthalmic surgeon: MBA; Consultant otolaryngologists (ENT surgeons): BK; Histopathologic examination (pathologist): MJA; Mycological analysis: PB; Analysis and interpretation of data: AA, GRP, ASD, SSH; Drafting of the manuscript: $A A, A K, H B$; Final approval of the manuscript and agreement to be accountable for all aspects of the paper: AA, GRP, ASD, SSH.

\section{Funding}

The authors have no support or funding to report.

Availability of data and materials

All data generated or analyzed during this study included in this article.

\section{Ethics approval and consent to participate}

The ethics committee approved the study protocol at professor Alborzi clinical microbiology research center, Shiraz University of Medical Sciences. The study protocol conformed to the ethical guidelines of the 1975 Helsinki Declaration.

\section{Consent for publication}

We have written informed consent obtained from the parents of the patients for publication of this case report and any accompanying images.

\section{Competing interests}

The authors declare that they have no competing interests.

\section{Author details}

${ }^{1}$ Professor Alborzi Clinical Microbiology Research Center, Shiraz University of Medical Sciences, Shiraz, Iran. ${ }^{2}$ Shiraz University of Medical Sciences, Namazi Hospital, 7193711351, Zand Ave, Shiraz, Iran. ${ }^{3}$ Department and Research Center of Otolaryngology, Head and Neck Surgery, Shiraz University of Medical Sciences, Shiraz, Iran. ${ }^{4}$ Department of Pathology, Shiraz University of Medical Sciences, Shiraz, Iran.

Received: 17 June 2020 Accepted: 30 September 2020

Published online: 19 October 2020

\section{References}

1. Petrikkos G, Skiada A, Lortholary O, Roilides E, Walsh TJ, Kontoyiannis DP. Epidemiology and clinical manifestations of mucormycosis. Clin Infect Dis. 2012;54(suppl_1):S23-34.

2. Dolatabadi S, Ahmadi B, Rezaei-Matehkolaei A, Zarrinfar H, Skiada A, Mirhendi $\mathrm{H}$, et al. Mucormycosis in Iran: a six-year retrospective experience. J Mycol Med. 2018;28(2):269-73.

3. Vaezi A, Moazeni M, Rahimi MT, de Hoog S, Badali H. Mucormycosis in Iran: a systematic review. Mycoses. 2016;59(7):402-15.

4. Badiee P, Arastefar A, Jafarian H. Comparison of histopathological analysis, culture and polymerase chain reaction assays to detect mucormycosis in biopsy and blood specimens. Iran J Microbiol. 2013;5(4):406.

5. Bonifaz A, Tirado-Sánchez A, Calderón L, Romero-Cabello R, Kassack J, Ponce RM, et al. Mucormycosis in children: a study of 22 cases in a Mexican hospital. Mycoses. 2014;57:79-84. 
6. Chamilos G, Lewis RE, Kontoyiannis DP. Delaying amphotericin B-based frontline therapy significantly increases mortality among patients with hematologic malignancy who have zygomycosis. Clin Infect Dis. 2008;47(4):503-9.

7. Scott E. Olitsky JDM. Abnormalities of Pupil and Iris,. In: Robert M, Kliegman JSG, editor. Nelson textbook of pediatrics 21st edition. Philadelphia: Elsevier; 2019. p. 3351.

8. Badiee P, Jafarpour Z, Alborzi A, Haddadi P, Rasuli M, Kalani M. Orbital mucormycosis in an immunocompetent individual. Iran J Microbiol. 2012; 4(4):210

9. Wadsworth JAC. Ocular Mucormycosis *: report of a case. Am J Ophthalmol. 1951;34(3):405-9.

10. Ziakas PD, Adraktas P, Ntountas J, Skarpidi E, Filippi V, Kechagias D, et al. Isolated orbital mucormycosis: a rare presentation ending in a fatal outcome. Int J Infect Dis. 2009;13(1):112-4

11. Guevara JKH. Isolated orbital mucormycosis in an immunocompetent adolescent. Med Stud Res J. 2014;3:55-9.

12. Badiee P, Gandomi B, Sabz G, Khodami B, Choopanizadeh M, Jafarian H. Evaluation of nested PCR in diagnosis of fungal rhinosinusitis. Iran J Microbiol. 2015;7(1):62

13. Bethge W, Schmalzing M, Stuhler G, Schumacher U, Krober S, Horger M, et al. Mucormycoses in patients with hematologic malignancies: an emerging fungal infection. Haematologica. 2005;90(Suppl):ECR22-ECR.

14. Enoch DA, Yang H, Aliyu SH, Micallef C. The changing epidemiology of invasive fungal infections. Human Fungal Pathogen Identification: Springer; 2017. p. 17-65.

15. Pana ZD, Seidel D, Skiada A, Groll AH, Petrikkos G, Cornely OA, et al. Invasive mucormycosis in children: an epidemiologic study in European and non-European countries based on two registries. BMC Infect Dis. 2016;16(1):667.

16. Elinav H, Zimhony O, Cohen M, Marcovich A, Benenson S. Rhinocerebral mucormycosis in patients without predisposing medical conditions: a review of the literature. Clin Microbiol Infect. 2009;15(7):693-7.

17. Lanternier F, Dannaoui E, Morizot G, Elie C, Garcia-Hermoso D, Huerre M, et al. A global analysis of mucormycosis in France: the RetroZygo Study (2005-2007). Clin Infect Dis. 2012;54(suppl_1):S35-43.

18. Roden MM, Zaoutis TE, Buchanan WL, Knudsen TA, Sarkisova TA, Schaufele RL, et al. Epidemiology and outcome of zygomycosis: a review of 929 reported cases. Clin Infect Dis. 2005:41(5):634-53.

19. Mignogna MD, Fortuna G, Leuci S, Adamo D, Ruoppo E, Siano M, et al. Mucormycosis in immunocompetent patients: a case-series of patients with maxillary sinus involvement and a critical review of the literature. Int J Infect Dis. 2011;15(8):e533-e40.

20. Mukherjee B, Raichura ND, Alam MS. Fungal infections of the orbit. Indian J Ophthalmol. 2016;64(5):337.

21. Ribes JA, Vanover-Sams CL, Baker DJ. Zygomycetes in human disease. Clin Microbiol Rev. 2000;13(2):236-301.

22. Habroosh FA, Eatamadi H, Mohamed RM. Concomitant orbital aspergillosis and mucormycosis in a 17 months old immunocompetent child. Saudi J Ophthalmol. 2017;31(3):193-5.

23. Słowik M, Biernat MM, Urbaniak-Kujda D, Kapelko-Słowik K, Misiuk-Hojło M. Mycotic infections of the eye. Adv Clin Exp Med. 2015;24(6):1113-7.

24. Prabhu S, Alqahtani M, Al Shehabi M. A fatal case of rhinocerebral mucormycosis of the jaw after dental extractions and review of literature. J Infect Public Health. 2018;11(3):301-3.

25. Pak J, Tucci VT, Vincent AL, Sandin RL, Greene JN. Mucormycosis in immunochallenged patients. J Emerg Trauma Shock. 2008;1(2):106.

26. Mcnulty JS. Rhinocerebral mucormycosis: predisposing factors. Laryngoscope. 1982;92(10):1140-3.

27. Xia Z-K, Wang W-L, Yang R-Y. Slowly progressive cutaneous, rhinofacial, and pulmonary mucormycosis caused by Mucor irregularis in an immunocompetent woman. Clin Infect Dis. 2013;56(7):993-5.

28. Radner AB, Witt MD, Edwards JE Jr. Acute invasive rhinocerebral zygomycosis in an otherwise healthy patient: case report and review. Clin Infect Dis. 1995;20(1):163-6.

29. Zapico ADV, Suarez AR, Encinas PM, Angulo CM, Pozuelo EC. Mucormycosis of the sphenoid sinus in an otherwise healthy patient. Case report and literature review. J Laryngol Otol. 1996;110(5):471-3.

30. Baum JL. Rhino-orbital Mucormycosis: occurring in an otherwise apparently healthy individual. Am J Ophthalmol. 1967;63(2):335-9.

31. Blodi FC, Hannah FT, Wadsworth JA. Lethal orbitocerebral phycomycosis in otherwise healthy children. Am J Ophthalmol. 1969;67(5):698-705.
32. Swain S, Sahu M, Banerjee A. Non-sinonasal isolated facio-orbital mucormycosis-a case report. J Mycol Med. 2018;28(3):538-41.

33. Green WH, Goldberg HI, Wohl GT. Mucormycosis infection of the craniofacial structures. Am J Roentgenol. 1967;101 (4):802-6.

34. Dooley DP, Hollsten DA, Grimes SR, Moss JJ. Indolent orbital apex syndrome caused by occult mucormycosis. J Clin Neuro Ophthalmol. 1992;12(4):245-9.

35. Yeh S, Foroozan R. Orbital apex syndrome. Curr Opin Ophthalmol. 2004; 15(6):490-8.

36. Kermani W, Bouttay R, Belcadhi M, Zaghouani H, Ali MB, Abdelkéfi M. ENT mucormycosis. Report of 4 cases. Eur Ann Otorhinolaryngol Head Neck Dis. 2016;133(2):83-6.

37. Farooq AV, Patel RM, Lin AY, Setabutr P, Sartori J, Aakalu VK. Fungal orbital cellulitis: presenting features, management and outcomes at a referral center. Orbit. 2015;34(3):152-9.

38. Tissot F, Agrawal S, Pagano L, Petrikkos G, Groll AH, Skiada A, et al. ECIL-6 guidelines for the treatment of invasive candidiasis, aspergillosis and mucormycosis in leukemia and hematopoietic stem cell transplant patients. Haematologica. 2017;102(3):433-44.

39. Sen ZS, Kara TT, Keskin S, Ozen G, Ornek F, Alioglu B. Preseptal and orbital cellulitis in childhood: the experience of Ankara training and research hospital. J Pediatr Res. 2019;1:64.

40. Santos JC, Pinto S, Ferreira S, Maia C, Alves S, da Silva V. Pediatric preseptal and orbital cellulitis: a 10-year experience. Int J Pediatr Otorhinolaryngol. 2019;120:82-8

41. Rahbar R, Robson CD, Petersen RA, DiCanzio J, Rosbe KW, McGill TJ, et al. Management of orbital subperiosteal abscess in children. Arch Otolaryngol Head Neck Surg. 2001;127(3):281-6.

\section{Publisher's Note}

Springer Nature remains neutral with regard to jurisdictional claims in published maps and institutional affiliations.

Ready to submit your research? Choose BMC and benefit from:

- fast, convenient online submission

- thorough peer review by experienced researchers in your field

- rapid publication on acceptance

- support for research data, including large and complex data types

- gold Open Access which fosters wider collaboration and increased citations

- maximum visibility for your research: over $100 \mathrm{M}$ website views per year

At $\mathrm{BMC}$, research is always in progress.

Learn more biomedcentral.com/submissions 